\title{
Ação de tinturas e óleos essenciais de plantas medicinais sobre o crestamento bacteriano comum do feijoeiro e na produção de proteínas de indução de resistência
}

\author{
Sandra Cristina Vigo ${ }^{1}$, Antonio Carlos Maringoni ${ }^{1}$, Renata de Cássia Camara ${ }^{1}$ \& Giuseppina P.P. Lima ${ }^{2}$
}

${ }^{1}$ Departamento de Produção Vegetal-Faculdade de Ciências Agronômicas, UNESP. CP 237, Botucatu, SP, 18610-307. ²Departamento de Química e Bioquímica, Instituto de Biologia, UNESP. CP 1510 Botucatu, SP, 18618-000, ${ }^{1}$ bolsista CNPq

Autor para correspondência: Sandra Cristina Vigo-Schultz: (sandracvigo@yahoo.com.br)

Data de chegada: 04/08/2008. Aceito para publicação em: 15/06/2009.

1602

\section{RESUMO}

Vigo, S.C., Maringoni, A.C., Câmara, R. de C., Lima, G.P.P. Ação de tinturas e óleos essenciais de plantas medicinais sobre o crestamento bacteriano comum do feijoeiro e na produção de proteínas de indução de resistência. Summa Phytopathologica, v.35, n.4, p.293-304, 2009

A exploração da atividade biológica de compostos secundários presentes nas tinturas ou em óleos essenciais de plantas podem representar, ao lado da indução de resistência, mais uma forma potencial de controle de doenças em plantas cultivadas. O presente trabalho objetivou avaliar o potencial de tinturas de Lippia alba, Lippia sidoides, Mikania glomerata, Equisetum sp. e Hedera helix e óleos essenciais de Rosmarinus officinalis e Cinnamomum zeylanicum nas atividades in vitro, in vivo e na produção de proteínas na indução de resistência, em plantas de feijão vagem cultivar Bragança. Os resultados obtidos demonstraram que as tinturas de $L$. alba e $L$. sidoides e os óleos essenciais (R. officinalis e C. zeylanicum) apresentaram atividade in vitro aos isolados de Xanthomonas axonopodis pv. phaseoli. Todas as tinturas ensaiadas apresentaram menores valores do progresso da doença (AACPD), em relação à testemunha, merecendo destaque a tintura de $L$. alba, que estavam correlacionadas com os maiores teores de polifenoloxidase, peroxidase e proteínas solúveis totais, evidenciando uma possível indução de resistência. Os óleos essenciais não apresentaram diferença na AACPD e nem na indução de proteínas.

Palavras-chave adicionais: Phaseolus vulgaris, Xanthomonas axonopodis pv. phaseoli, resistência sistêmica adquirida, planta medicinal, metabólitos secundários, defensivos naturais.

\section{ABSTRACT}

Vigo, S.C., Maringoni, A.C., Câmara, R. de C., Lima, G.P.P. Action of medicinal plants tinctures and essential oils to the bean common bacterial blight and on protein production of resistance induction. Summa Phytopathologica, v.35, n.4, p.293-304, 2009

Additionally to resistance inducers, the exploitation of secondary compounds biological activity present in plants alcohol extracts or essential oils could potential way to control diseases in cultivated plants. This aimed to evaluate the potential of Lippia alba, Lippia sidoides, Mikania glomerata, Equisetum sp. and Hedera helix alcohol extracts and, Rosmarinus officinalis and Cinnamomum zeylanicum essential oils on in vitro and in vivo activity, and protein production on resistance induction in snap beans Bragança cultivar. Results showed in vitro activity against Xanthomonas axonopodis pv. phaseoli for $L$. alba and $L$. sidoides extracts, and essential oils. Although all alcohol extracts have showed the lowest area under the disease progress curve (AUPDC) values compared to control treatment, L. alba extract must be highlighted due to its correlation to the highest poliphenoloxidases, peroxidases and total soluble proteins values which evidences a possible resistance induction. Essential oils did not show difference on AUPDC nor protein induction.

Keywords: Phaseolus vulgaris, Xanthomonas axonopodis pv. phaseoli, acquired systemic resistance, medicinal plant, secondary metabolites, natural pesticides

O feijoeiro é afetado por vários tipos de patógenos que causam doenças e acarretam perdas significativas na produção. Entre estes o horticultor têm se preocupado com a bactéria Xanthomonas axonopodis pv. phaseoli, agente causal do crestamento bacteriano comum, que possui grande importância para a cultura devido sua distribuição quase generalizada, e os danos severos na produtividade (02).

A eficácia do controle químico do crestamento bacteriano comum do feijoeiro, através de pulverização das plantas com produtos bactericidas, tem sido de pouca magnitude nas lavouras, devido à baixa eficiência destes (03).

Um dos enfoques da agricultura de base ecológica é o controle alternativo de doenças, o qual inclui o controle biológico e a indução de resistência em plantas e o uso de produtos naturais com atividade antimicrobiana e/ou indutora de resistência (16). A resistência induzida tem sido demonstrada em diversas espécies de plantas, ocorrendo em resposta ao tratamento com elicitores, que podem ser bióticos ou abióticos, dentre os quais pode-se citar os extratos vegetais, os óleos essenciais, produtos químicos, fungos, entre outros (19). Este tipo de controle provavelmente se tornará um componente importante no manejo de doenças, principalmente daquelas onde os métodos atuais mostram-se pouco efetivos (13).

Os mecanismos ativos de defesa das plantas contra fitopatógenos envolvem alterações metabólicas que estão correlacionadas com mudanças na atividade de enzimas chaves envolvidas na síntese de lignina e fitoalexinas, como a peroxidase, a polifenoloxidase e 
compostos fenólicos (14).

Trabalhos desenvolvidos com extratos ou óleos essenciais, obtidos a partir de plantas medicinais, têm indicado o potencial delas no controle de fitopatógenos, tanto por sua ação direta sobre os patógenos, inibindo seu crescimento, quanto pela indução de fitoalexinas, indicando compostos com característica de eliciadores (17).

Diante do exposto, este trabalho foi realizado com os objetivos de estudar o efeito das tinturas vegetais de Lippia alba (erva cidreira), Lippia sidoides (alecrim pimenta) Mikania glomerata (guaco), Equisetum sp. (cavalinha) e Hedera helix (hera) e dos óleos essenciais de Rosmarinus officinalis (alecrim) e Cinnamomum zeylanicum (canela) no crescimento in vitro de $X$. axonopodis pv. phaseolis, na indução de resistência ao crestamento bacteriano comum em feijão vagem cultivar Bragança, bem como a produção de peroxidase, polifenoloxidase e proteínas solúveis totais em plantas tratadas e não tratadas com a aplicação dos produtos vegetais.

\section{MATERIAL E MÉTODOS}

\section{Obtenção das tinturas e óleos essenciais de plantas medicinais}

As plantas medicinais, produzidas no Campus da UNESP em Botucatu, foram coletadas ao entardecer e utilizadas na forma de tintura vegetal. A tintura vegetal foi obtida através de maceração de folhas frescas $(200 \mathrm{~g})$ em álcool etílico $70 \%(1000 \mathrm{~mL})$ por sete dias, em temperatura ambiente e no escuro. Posteriormente, a tintura foi filtrada em gaze e em papel filtro, Whatman $\mathrm{n}^{\circ} 01$, e preservadas sob refrigeração para utilização nos diferentes ensaios. Essa tintura-mãe foi considerada como $100 \%$.

Os óleos essenciais foram obtidos da indústria Bioessência Produtos Naturais Ltda, localizada à Avenida Industrial, 827, Distrito Industrial, Barra Bonita, São Paulo.

\section{Atividade antimicrobiana in vitro das tinturas e óleos essenciais}

Visando verificar a ação in vitro das tinturas e óleos essenciais das plantas medicinais dois isolados de Xap (101D e UFV50) foram cultivados em $50 \mathrm{~mL}$ de nutriente líquido, durante $48 \mathrm{~h}$, a $28{ }^{\circ} \mathrm{C}$. Seguida a incubação, os isolados foram transferidos individualmente para recipientes contendo meio de cultura NSA fundente, a $45-50^{\circ} \mathrm{C}$, na proporção de uma parte de suspensão bacteriana para nove partes de meio de cultura. Essa mistura foi transferida para placas de Petri $(20 \mathrm{~mL})$, deixando-a solidificar sob condições ambientes. Após a solidificação foram realizados perfurações (pocinhos) de $5 \mathrm{~mm}$ de diâmetro no meio de cultura e acrescentado $40 \mu \mathrm{L}$ das tinturas e óleos essenciais nas concentrações de $0,1,5,10,50$ e $100 \%$ (10). Os óleos essenciais foram solubilizados em água destilada contendo leite em pó desnatado (18 $\left.\mathrm{g} \mathrm{L}^{-1}\right)$ como emulsificante, após autoclavar (07). Álcool etílico $70 \%$ foi utilizado como testemunha para as tinturas e água destilada contendo leite em pó desnatado como testemunha para os óleos essenciais.

As placas foram incubadas a $28^{\circ} \mathrm{C}$, durante $48 \mathrm{~h}$ e, em seguida, aferidos em milímetros os diâmetros perpendiculares dos halos de inibição formados ao redor dos "pocinhos". O delineamento experimental empregado foi o inteiramente casualizado com quatro repetições e seis tratamentos distribuídos nas escavações das placas (seis por placa), sendo cada repetição representada por uma placa de Petri.
Indução de resistência em feijão vagem ao crestamento bacteriano comum

Sementes de feijão vagem, cultivar Bragança, foram semeadas em vasos de $3 \mathrm{~L}$ de capacidade contendo substrato autoclavado constituído de um terço de areia grossa, um terço de solo e um terço de esterco de curral curtido, acrescido de calcário dolomítico e adubo químico conforme a análise de solo (21), sob condições de casa de vegetação. Foram semeadas cinco sementes de feijão por vaso e, após a germinação, selecionou-se as plantas com desenvolvimento normal, deixando três plantas por vaso. $\mathrm{O}$ delineamento experimental foi o de blocos casualizados com cinco repetições, esquema fatorial 5 tratamentos $\mathrm{x} 3$ épocas de aplicação para as tinturas e 4 tratamentos $\mathrm{x}$ 2 épocas de aplicação para os óleos essenciais. Cada vaso contendo três plantas representou uma repetição para tratamento e época de aplicação.

Os tratamentos para as tinturas foram: pulverização cinco dias antes da inoculação, cinco dias antes e cinco dias após a inoculação e cinco dias após a inoculação. Para os óleos essenciais foram: pulverização cinco dias antes da inoculação e cinco dias após a inoculação.

As tinturas de L. alba, L. sidoides, M. glomerata, Equisetum sp. e $H$. hélix foram pulverizados nas folhas das plantas, nas concentrações de $0,1,5,10$ e $20 \%$. Os óleos essenciais de alecrim e canela foram pulverizados nas folhas das plantas de feijão vagem nas concentrações de $0,5 \%$ para o óleo de alecrim e $0,1 \%$ para o óleo de canela, baseadas em pré-testes de fitoxicidade para feijão vagem. Para tal, foi utilizado um pulverizador manual com 1,5 litros de capacidade e bico de pulverização do tipo leque.

Foi realizada a inoculação nas folhas primárias, aos quinze dias após a emergência das plantas, para os tratamentos com tinturas e inoculação nos folíolos da primeira, segunda e terceira folhas trifolioladas, aos 25 dias após a emergência das plantas, para os tratamentos com óleos essenciais através do método de agulhas múltiplas (01), com o isolado de Xap UFV 50, na concentração de $10^{8}$ ufc $\mathrm{mL}^{-1}$.

A avaliação da severidade de sintomas da doença nos folíolos foi realizada aos 12, 15 e 18 dias após a inoculação, através da escala de notas de 1 a 5, conforme Maringoni et al. (09): 1 - sem sintoma, 2 - até $25 \%$ de amarelecimento e/ou necrose na área inoculada, 3 - 26 a 50\% de amarelecimento e/ou necrose na área inoculada, $4-51$ a 75\% de amarelecimento e/ou necrose na área inoculada, 5 - acima de $75 \%$ de amarelecimento e/ou necrose na área inoculada. Com os resultados obtidos nas avaliações foi calculada a área abaixo da curva do progresso da doença (AACPD), conforme Schneider et al. (15), e os valores foram submetidos à análise de variância e a testes de comparação de médias, com o auxílio do programa estatístico ASSISTAT (18).

\section{Análises bioquímicas}

Para as análises de polifenoloxidase, peroxidase e teor de proteínas foi utilizado ensaio em casa de vegetação com vasos, utilizando-se os mesmos tratamentos e delineamentos descrito no item anterior.

Retirou-se uma folha primária de cada repetição de plantas não inoculadas e inoculadas (cinco dias após os tratamentos), sendo cinco coletas no total, em cinco épocas (concomitantemente, 3, 5, 8 e 10 dias após o tratamento). Para tanto foram pulverizados nas folhas os extratos etanólicos na concentração de $20 \%$ e os óleos essenciais de alecrim e canela, nas concentrações de 0,5 e $0,1 \%$, respectivamente.

As amostras após pesagem, foram embaladas, congeladas em 
nitrogênio líquido e mantidas a temperatura de $-20{ }^{\circ} \mathrm{C}$. Foram processadas para as análises, através da trituração em $5 \mathrm{~mL}$ de tampão fosfato $0,2 \mathrm{M}, \mathrm{pH} 6,7$ à temperatura entre 0 e $4{ }^{\circ} \mathrm{C}$ e centrifugação do homogeneizado obtido, por $15 \mathrm{~min}$ a $10000 \mathrm{~g}$ (peroxidase (POD) e proteínas solúveis totais). Para a atividade de polifenoloxidase (PFO) foi utilizado tampão fosfato $0,05 \mathrm{M}, \mathrm{pH}$ 6,0 na trituração. $\mathrm{O}$ sobrenadante foi armazenado em frascos de vidro, mantidos em freezer a $-20{ }^{\circ} \mathrm{C}$, para ser utilizado como extrato nas análises.

O teor de PFO foi determinado de acordo com o método de Cano et al. (05) modificado, que consiste em extrair essa enzima pela reação entre o substrato e o catecol. A reação ocorrida, em banho-maria, entre $0,3 \mathrm{~mL}$ do extrato e $1,85 \mathrm{~mL}$ de solução de catecol (pyrocathecol 0,1 $\mathrm{M}$ em tampão fosfato $0,05 \mathrm{M}, \mathrm{pH} 6,0)$, durante $30 \mathrm{~min}$, a $30{ }^{\circ} \mathrm{C}$, foi interrompida após a adição de $0,8 \mathrm{~mL}$ de ácido perclórico a $5 \%$ $\left(\mathrm{HClO}_{4}\right)$. A leitura da absorbância foi realizada em espectrofotômetro no comprimento de onda de $395 \mathrm{~nm}$. O teor de PFO foi obtido aplicando-se a fórmula abaixo, calculando-se em U.A. $\mathrm{g}^{-1}$ massa fresca $\min ^{-1}$.

O teor de POD foi determinado pela reação dos extratos com as soluções A (20 mM de $\mathrm{H}_{2} \mathrm{O}_{2}+$ tampão fosfato $\left.0,2 \mathrm{M}, \mathrm{pH} 6,7\right)$ e B ( $4 \mathrm{mM}$ de aminoantipirina em $10 \mathrm{mM}$ de fenol) durante 5 min a $30^{\circ} \mathrm{C}$, parando-se a reação com $2 \mathrm{~mL}$ de álcool etílico absoluto, fazendo-se em seguida a leitura em espectrofotômetro, no comprimento de onda de $505 \mathrm{~nm}$ (08). O teor de peroxidase foi calculado com o emprego de fórmula, calculando-se em $\mu \mathrm{Mol} \mathrm{H}_{2} \mathrm{O}_{2}$ decomposto $\mathrm{g}^{-1}$ massa fresca $\min ^{-1}$.

O teor de proteínas totais solúveis foi determinado pelo método de Bradford (04), através da reação entre uma alíquota do extrato vegetal e $5 \mathrm{~mL}$ do reativo de Bradford (100 mg de brilhante Blue $\mathrm{G}+$ $50 \mathrm{~mL}$ de etanol $95 \%+100 \mathrm{~mL} \mathrm{H}_{3} \mathrm{PO}_{4} 85 \%$ + água destilada q. s. p. $1 \mathrm{~L}$ ), durante $5 \mathrm{~min}$, realizando-se a leitura da absorbância em espectrofotômetro a $595 \mathrm{~nm}$. Os valores obtidos na leitura foram substituídos na equação da curva de eficiência (caseína como padrão) e expressos em mg proteína $\mathrm{g}^{-1}$ massa fresca.

\section{RESULTADOS E DISCUSSÃO}

Entre as tinturas estudadas, as de L. alba e L. sidoides, na concentração de $100 \%$, e a de L. alba, na concentração de $50 \%$, promoveram a formação de halo de inibição ao isolado $101 \mathrm{D}$, enquanto que para o isolado UFV 50, apenas a tintura de L. sidoides, nas concentrações de 50 e $100 \%$, promoveu a formação de halos. As demais tinturas avaliadas, em todas as concentrações, não foram capazes de inibir o crescimento dos isolados de X. axonopodis pv. phaseoli ensaiados. Esses resultados foram contrários àqueles obtidos por Morais et al. (11), que observaram a ação inibitória in vitro de tinturas L. alba e de Equisetum spp. à cinco isolados de $X$. axonopodis pv. phaseoli. Conforme esses autores, houve variação na sensibilidade dos isolados às tinturas avaliadas, sendo o isolado Feij-20, o mais sensível. Este resultado concorda com os daqui descritos, pois o isolado $101 \mathrm{D}$ apresentou maior sensibilidade in vitro quando comparado com o isolado UFV 50.

Estudos conduzidos por Vigo-Schultz et al. (23) demonstraram a ação inibitória in vitro da tintura de $M$. glomerata a $X$. campestris $\mathrm{pv}$. campestris nas concentrações a partir de $250 \mathrm{mg} \mathrm{L}^{-1}$. Resultados semelhantes eram esperados no presente trabalho, com a tintura dessa espécie vegetal, porém não foram constatadas atividades inibitórias aos isolados de $X$. axonopodis pv. phaseoli aqui avaliados. .
Os óleos essenciais de R. officinalis e C. zeylanicum apresentaram ação inibitória in vitro aos isolados de $X$. axonopodis pv. phaseoli ensaiados. Foi observada a presença de halos de inibição para $R$. officinalis a partir da concentração de $1 \%$, e para o isolado UFV 50, a partir da concentração de 5\%. Pesquisas desenvolvidas principalmente com fungos de pós colheita em banana evidenciaram a redução no peso micelial na presença de $0,3 \%$ v/v de óleo de $C$. zeylanicum, devido a presença dos compostos antimicrobianos cinnamaldeído e eugenol (13).

Com relação ao tratamento das plantas de feijoeiro com as diferentes tinturas e óleos essenciais nas concentrações avaliadas e nos diferentes períodos de aplicação, evidenciaram que todas as tinturas apresentaram efeito no controle do crestamento bacteriano comum, sendo que as concentrações de 5 e $20 \%$ de $L$. alba (Tabela 1), 5,10 e $20 \%$ de L. sidoides e M. glomerata (Tabelas 2 e 3), 10 e $20 \%$ de Equisetum sp. (Tabela 4) e 5 e $20 \%$ de H. helix (Tabela 5) foram as que propiciaram os menores valores da AACPD. Os óleos essenciais não evidenciaram essa ação no controle do crestamento bacteriano comum (Tabela 6). Para o período de aplicação de L. alba, os menores valores de AACPD observados foram aos cinco dias antes da inoculação (Tabela 1), para M. glomerata aos cinco dias antes e cinco dias após a inoculação (Tabela 3 ) e para $H$. helix, quando observou-se interação entre tratamentos e épocas de aplicação, os menores valores de AACPD foram observados aos cinco dias antes ( concentração de 5\%) e cinco

Tabela 1: Efeito da tintura de L. alba, em diferentes concentrações, sobre a ocorrência de sintomas (área abaixo da curva do progresso do crestamento bacteriano comum) em folhas de feijão vagem cultivar Bragança inoculadas com $X$. axonopodis pv. phaseoli, em três épocas de aplicação da tintura

\begin{tabular}{lcccc}
\hline \multirow{2}{*}{$\begin{array}{c}\text { Concentrações } \\
\text { da tintura (\%) }\end{array}$} & $\begin{array}{c}5 \text { dias } \\
\text { antes }\end{array}$ & $\begin{array}{c}5 \text { dias antes }+ \\
5 \text { dias após }\end{array}$ & $\begin{array}{c}5 \text { dias } \\
\text { após }\end{array}$ & Média \\
\hline 0 & 22,41 & 24,15 & 23,97 & $23,51 \mathrm{a}^{*}$ \\
1 & 22,35 & 21,12 & 22,38 & $21,95 \mathrm{~b}$ \\
5 & 20,97 & 20,76 & 22,20 & $21,31 \mathrm{bc}$ \\
10 & 21,42 & 22,41 & 22,80 & $22,21 \mathrm{ab}$ \\
20 & 19,50 & 20,97 & 20,85 & $20,44 \mathrm{c}$ \\
Média & $21,33 \mathrm{~b}$ & $21,88 \mathrm{ab}$ & $22,44 \mathrm{a}$ & \\
\hline CV $(\%) 6,20$ & \multicolumn{5}{c}{}
\end{tabular}

Médias seguidas pela mesma letra não diferem significativamente entre si pelo teste de Tukey, a 5\% de probabilidade

Tabela 2: Efeito da tintura de L. sidoides, em diferentes concentrações, sobre a ocorrência de sintomas (área abaixo da curva do progresso do crestamento bacteriano comum) em folhas de feijão vagem cultivar Bragança inoculadas com $X$. axonopodis pv. phaseoli, em três épocas de aplicação da tintura.

\begin{tabular}{llcll}
\hline \multirow{2}{*}{$\begin{array}{c}\text { Concentrações } \\
\text { da tintura (\%) }\end{array}$} & \begin{tabular}{c}
5 Épocas de aplicação \\
\cline { 2 - 5 }
\end{tabular} & $\begin{array}{c}5 \text { dias antes }+ \\
5 \text { dias após }\end{array}$ & $\begin{array}{c}5 \text { dias } \\
\text { após }\end{array}$ & Média \\
\hline 0 & 21,48 & 22,44 & 22,56 & $22,16 \mathrm{a}^{*}$ \\
1 & 22,44 & 20,55 & 20,91 & $21,30 \mathrm{ab}$ \\
5 & 20,91 & 19,44 & 19,74 & $20,03 \mathrm{bc}$ \\
10 & 19,26 & 19,56 & 19,38 & $19,40 \mathrm{c}$ \\
20 & 20,91 & 19,14 & 20,46 & $20,17 \mathrm{bc}$ \\
Média & 21,00 a & 20,23 a & $20,61 \mathrm{a}$ & \\
\hline CV (\%) 7,28 & \multicolumn{5}{c}{} \\
\hline
\end{tabular}

Médias seguidas pela mesma letra não diferem significativamente entre si pelo teste de Tukey, a $5 \%$ de probabilidade 
Tabela 3: Efeito da tintura de $M$. glomerata, em diferentes concentrações, sobre a ocorrência de sintomas (área abaixo da curva do progresso do crestamento bacteriano comum) em folhas de feijão vagem cultivar Bragança inoculadas com $X$. axonopodis pv. phaseoli, em três épocas de aplicação da tintura.

\begin{tabular}{ccccc}
\hline \multirow{2}{*}{$\begin{array}{c}\text { Concentrações } \\
\text { da tintura (\%) }\end{array}$} & $\begin{array}{c}5 \text { dias } \\
\text { antes }\end{array}$ & $\begin{array}{c}5 \text { dias antes }+ \\
5 \text { dias após }\end{array}$ & $\begin{array}{c}5 \text { dias } \\
\text { após }\end{array}$ & Média \\
\hline 0 & 27,27 & 26,91 & 27,42 & $27,20 \mathrm{a}^{*}$ \\
1 & 26,43 & 24,45 & 27,00 & $25,96 \mathrm{ab}$ \\
5 & 25,59 & 24,24 & 25,83 & $25,22 \mathrm{~b}$ \\
10 & 26,43 & 25,38 & 24,57 & $25,46 \mathrm{~b}$ \\
20 & 26,19 & 24,81 & 25,17 & $25,39 \mathrm{~b}$ \\
Média & $26,38 \mathrm{a}$ & $25,16 \mathrm{~b}$ & $26,00 \mathrm{ab}$ & \\
\hline
\end{tabular}

CV (\%) 5,55

"Médias seguidas pela mesma letra não diferem significativamente entre si pelo teste de Tukey, a 5\% de probabilidade

Tabela 4: Efeito da tintura de Equisetum sp., em diferentes concentrações, sobre a ocorrência de sintomas (área abaixo da curva do progresso do crestamento bacteriano comum) em folhas de feijão vagem cultivar Bragança inoculadas com $X$. axonopodis pv. phaseoli, em três épocas de aplicação da tintura.

\begin{tabular}{ccccc}
\hline \multirow{2}{*}{$\begin{array}{c}\text { Concentrações } \\
\text { da tintura (\%) }\end{array}$} & $\begin{array}{c}5 \text { dias } \\
\text { antes }\end{array}$ & $\begin{array}{c}5 \text { dias antes }+ \\
5 \text { dias após }\end{array}$ & $\begin{array}{c}5 \text { dias } \\
\text { após }\end{array}$ & Média \\
\hline \multirow{2}{*}{0} & 29,94 & 29,88 & 29,91 & $29,91 \mathrm{a}^{*}$ \\
1 & 29,82 & 29,22 & 29,61 & $29,55 \mathrm{a}$ \\
5 & 29,43 & 29,49 & 29,61 & $29,51 \mathrm{a}$ \\
10 & 28,92 & 28,95 & 29,79 & $29,22 \mathrm{ab}$ \\
20 & 27,69 & 28,43 & 29,18 & $28,43 \mathrm{~b}$ \\
Média & 29,16 a & 29,19 a & $29,62 \mathrm{a}$ & \\
\hline
\end{tabular}

CV (\%) 2,88

${ }^{*}$ Médias seguidas pela mesma letra não diferem significativamente entre si pelo teste de Tukey, a 5\% de probabilidade

Tabela 5: Efeito da tintura de $H$. helix, em diferentes concentrações, sobre a ocorrência de sintomas (área abaixo da curva do progresso do crestamento bacteriano comum) em folhas de feijão vagem cultivar Bragança inoculadas com $X$. axonopodis pv. phaseoli, em três épocas de aplicação da tintura

\begin{tabular}{cccc}
\hline \multirow{2}{*}{$\begin{array}{c}\text { Concentrações } \\
\text { da tintura (\%) }\end{array}$} & $\begin{array}{c}5 \text { Épocas de aplicação } \\
\text { antes }\end{array}$ & $\begin{array}{c}5 \text { dias antes }+ \\
5 \text { dias após }\end{array}$ & $\begin{array}{c}5 \text { dias } \\
\text { após }\end{array}$ \\
\cline { 2 - 4 } 0 & $23,64 \mathrm{aA}^{*}$ & $23,91 \mathrm{aA}$ & $23,61 \mathrm{aA}$ \\
1 & $22,59 \mathrm{aA}$ & $20,79 \mathrm{abA}$ & $21,51 \mathrm{aA}$ \\
5 & $17,70 \mathrm{bB}$ & $20,55 \mathrm{abAB}$ & $21,90 \mathrm{aA}$ \\
10 & $20,61 \mathrm{abA}$ & $21,24 \mathrm{abA}$ & $22,29 \mathrm{aA}$ \\
20 & $22,62 \mathrm{aA}$ & $18,30 \mathrm{bB}$ & $20,94 \mathrm{aAB}$ \\
\hline
\end{tabular}

CV (\%) 8,93

* Médias seguidas pela mesma letra minúscula na coluna, e maiúscula na linha, não diferem significativamente entre si pelo teste de Tukey, a $5 \%$ de probabilidade.

dias antes e após a inoculação (concentração de 20\%) (Tabela 5). Com relação as tinturas de $L$. sidoides e Equisetum sp. e os óleos essenciais de $R$. officinalis e C. zeylanicum (Tabelas 2, 4 e 6) não foram observadas diferenças entre os períodos de aplicação desses produtos, para os valores de AACPD observados.

Embora Paixão et al. (12) tenham observado redução na severidade do crestamento bacteriano comum em folíolos de feijão vagem, híbrido Flórida, pulverizados com as tinturas de L. alba, nas concentrações de
Tabela 6 - Efeito dos óleos essenciais de $R$. officinalis e $C$. zeylanicum, nas concentrações de 0,5 e $0,1 \%$ respectivamente, sobre a ocorrência de sintomas (área abaixo da curva do progresso do crestamento bacteriano comum) em folhas de feijão vagem cultivar Bragança inoculadas com $X$. axonopodis pv. phaseoli, em duas épocas de aplicação dos óleos essenciais.

\begin{tabular}{lccc}
\hline \multirow{2}{*}{ Tratamentos } & \multicolumn{4}{c}{ Épocas de aplicação } \\
\cline { 2 - 5 } & $\begin{array}{c}5 \text { dias } \\
\text { antes }\end{array}$ & $\begin{array}{c}5 \text { dias } \\
\text { após }\end{array}$ & Média \\
\hline Testemunha água & 28,53 & 27,39 & 27,96 a \\
Testemunha água + leite & 26,40 & 26,94 & 26,67 a \\
Óleo de Rosmarinus officinalis $0,5 \%$ & 26,52 & 27,27 & 26,89 a \\
Óleo de Cinnamomum zeylanicum $0,1 \%$ & 28,77 & 28,02 & 28,39 a \\
Média & 27,55 a & 27,40 a \\
\hline
\end{tabular}

CV (\%) 5,75

* Médias seguidas pela mesma letra não diferem significativamente entre si pelo teste de Tukey, a $5 \%$ de probabilidade

5 e $10 \%$ e não com a tintura de Equisetum sp., os resultados aqui observados concordam parcialmente com esses autores pois os valores da AACPD foram relativamente próximos entre os tratamentos.

Com relação a M. glomerata, Vigo-Schultz et al. (23) observaram que a tintura desta planta não ativou o processo de resistência em plantas de couve-flor à podridão negra, sendo este extrato com ação direta sobre o patógeno.

Nos ensaios com óleos essenciais de $R$. officinalis e $C$. zeylanicum não se constataram diferenças da AACPD em relação à testemunha água e a testemunha água + leite em pó. Isto pode ser devido à baixa concentração dos óleos essenciais em relação às tinturas, já que em pré-teste realizado observou-se um efeito tóxico dos mesmas em plantas de feijão vagem, não sendo fitotóxicos nas concentrações em que foram aqui ensaiadas. Tworkoski (22) observou que o óleo essencial de C. zeylanicum, na concentração de $5 \%$, teve alta atividade herbicida sobre as plantas invasoras Ambrosia artemisufolia, Chenopodium álbum e Sorghum halepense, pois causou a morte das mesmas, após dois dias da aplicação.

Com relação à atividade enzimática, verifica-se maior produção de polifenoloxidase e proteínas solúveis totais para as plantas tratadas com as tinturas de L. alba, L. sidoides, M. glomerata, Equisetum sp. e H. helix (Figuras 1 a 5), com o pico de produção respectivamente aos oito e cinco dias após a pulverização. Já para a peroxidase, incrementos na produção dessa enzima foram observados principalmente nas plantas pulverizadas com as tinturas de L. alba, M. glomerata e Equisetum sp. (Figuras 1, 3 e 4).

Os óleos essenciais empregados não acarretaram aumentos contrastantes em relação ao tratamento testemunha, quanto a produção de polifenoloxidase, peroxidase e proteínas solúveis totais (Figuras 6 e 7).

Evidencias apontam que as tinturas contempladas neste trabalho apresentaram ação indutora de resistência do feijão vagem ao crestamento bacteriano comum, visto pelas alterações na produção das enzimas e proteínas solúveis avaliadas e pelos menores valores da AACPD observados. Ao contrário de Vigo-Schultz et al. (23), onde ficou indicado que a indução de peroxidases ocorreu devido ao processo infeccioso por $X$. campestris pv. campestris e não em função dos tratamentos com a tintura de $M$. glomerata, em folhas tratadas e não tratadas de couve-flor, colhidas concomitantemente e as 24,48 e $72 \mathrm{~h}$ da pulverização da tintura e, após pulverização-inoculação.

As plantas inoculadas com o patógeno desafiante não apresentaram diferença na produção de polifenoloxidase, peroxidase e proteínas 


\section{Polifenoloxidase}
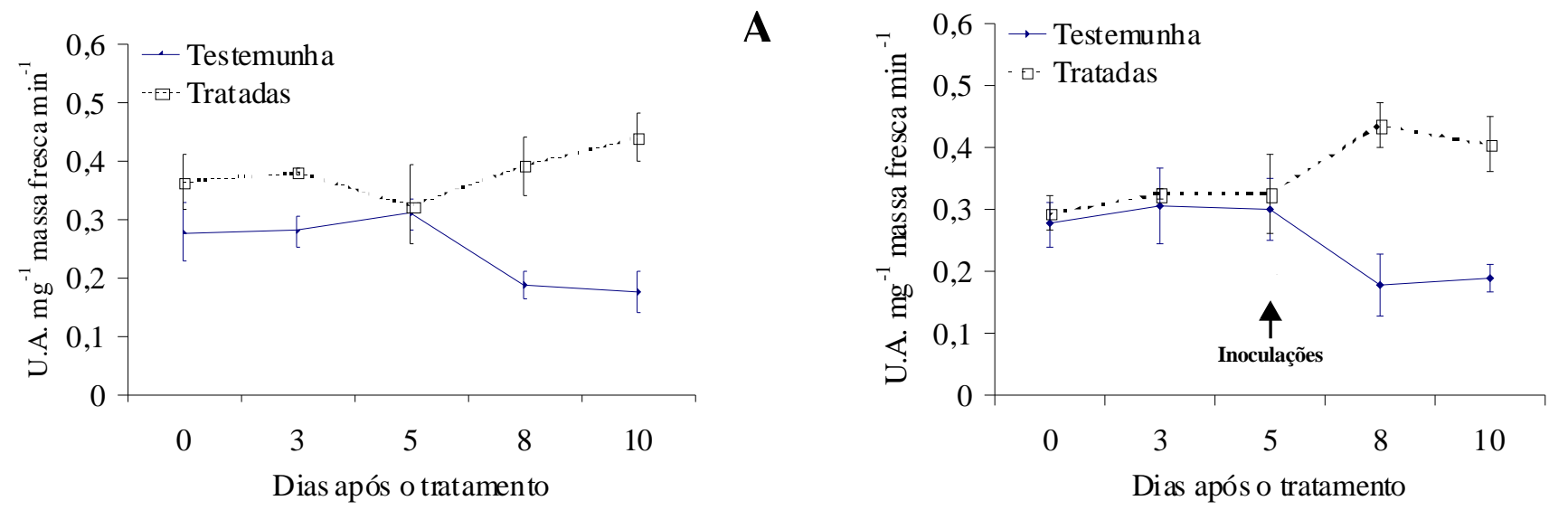

B

Peroxidase
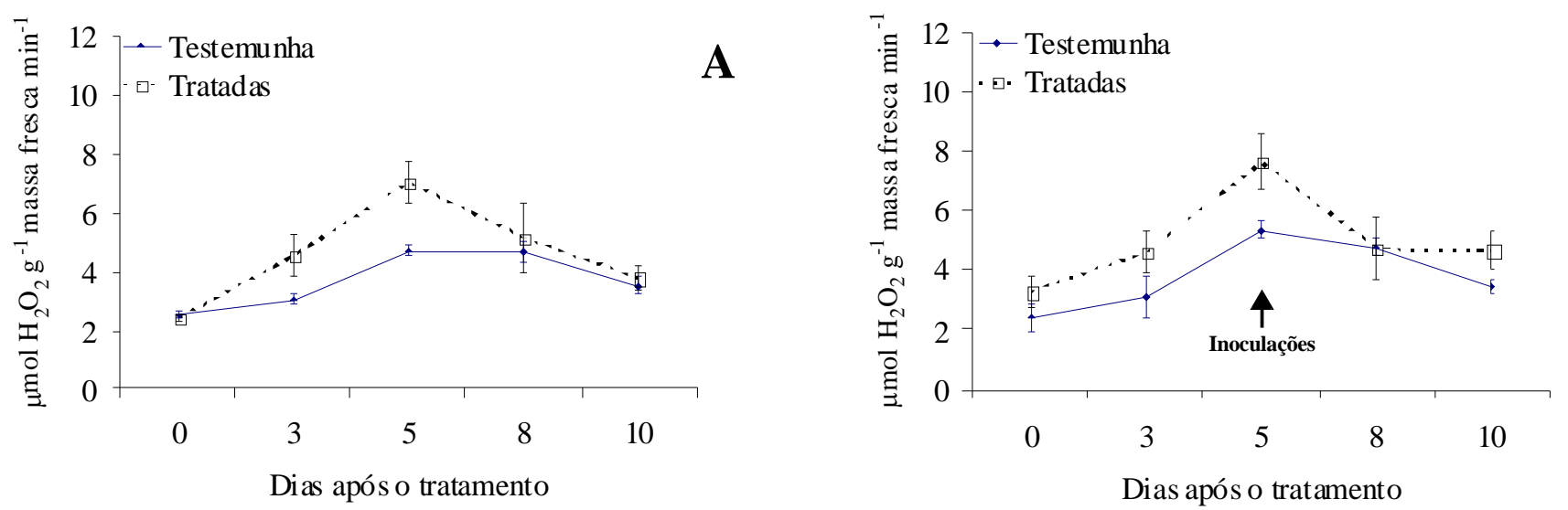

Proteínas solúveis totais

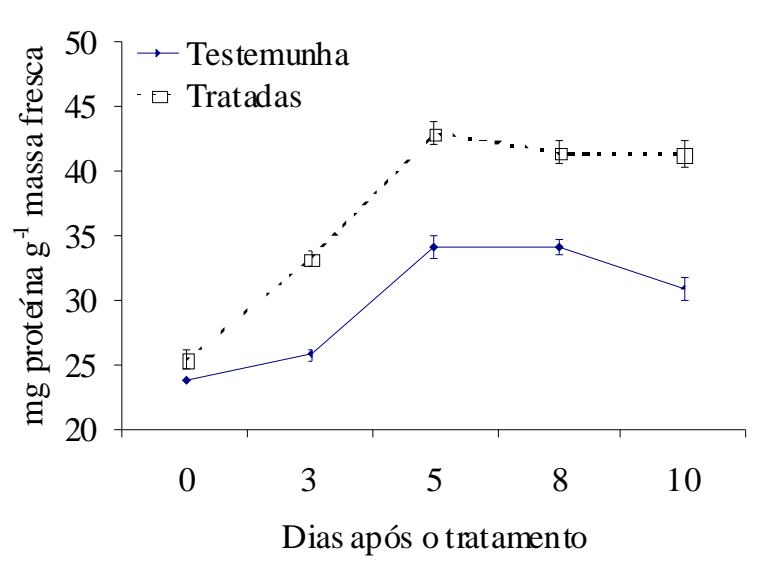

A

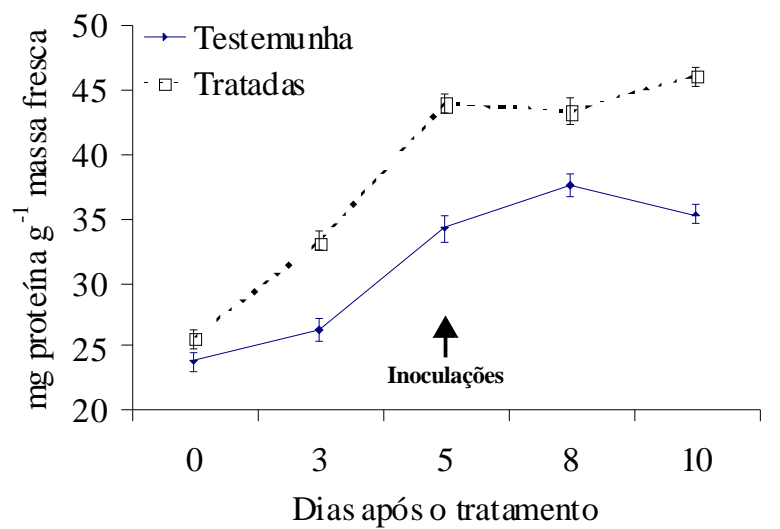

Figura 1 - Teor de polifenoloxidase, peroxidase e proteínas solúveis totais em folhas de feijão vagem cultivar Bragança pulverizadas com tintura de $L$. alba a $20 \%$, não inoculadas (A) e inoculadas (B) com X. axonopodis pv. phaseoli. Barras indicam a média \pm o erro padrão. 


\section{Polifenoloxidase}
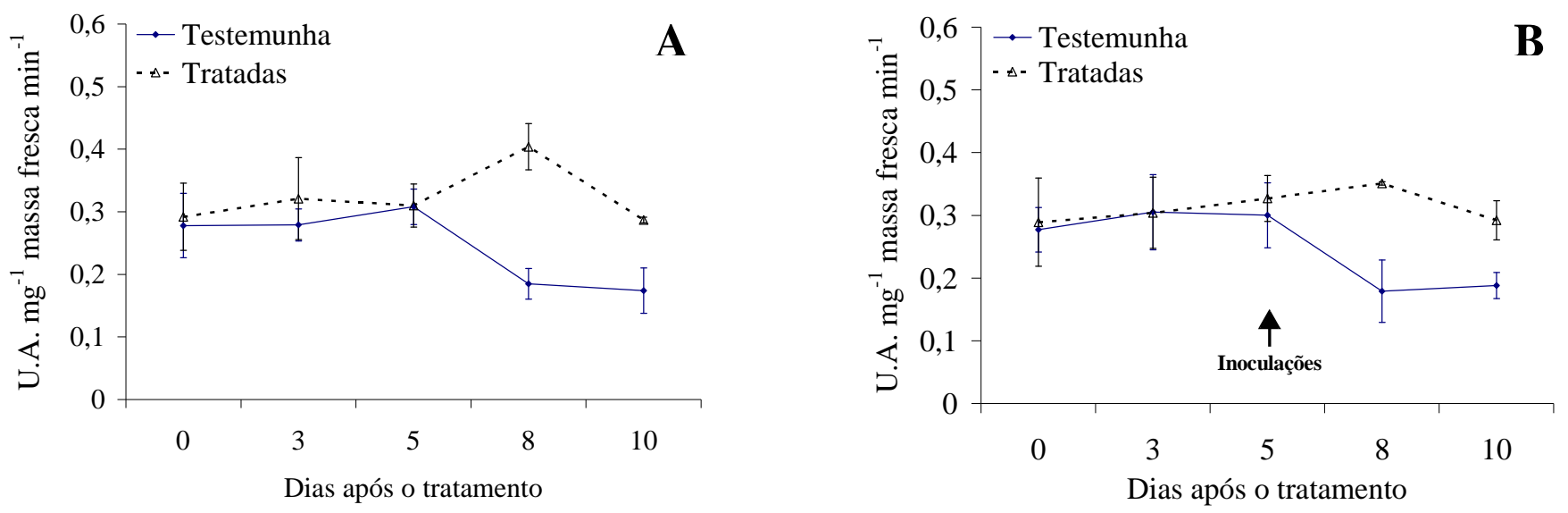

Peroxidase
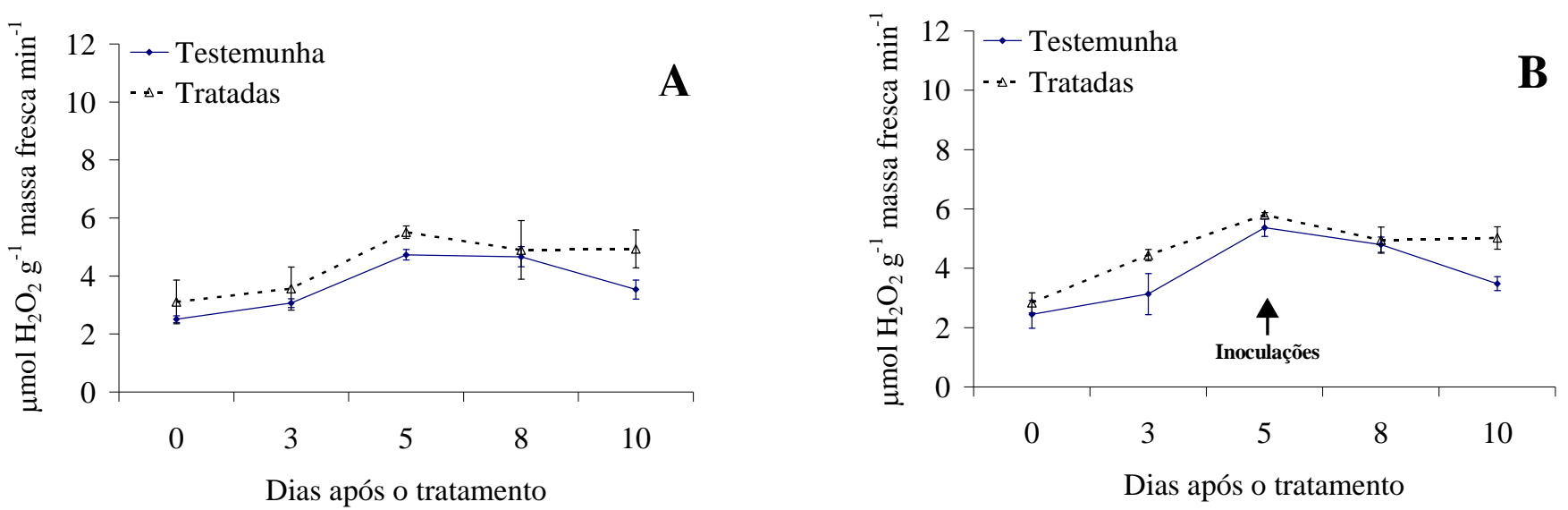

Proteínas solúveis totais
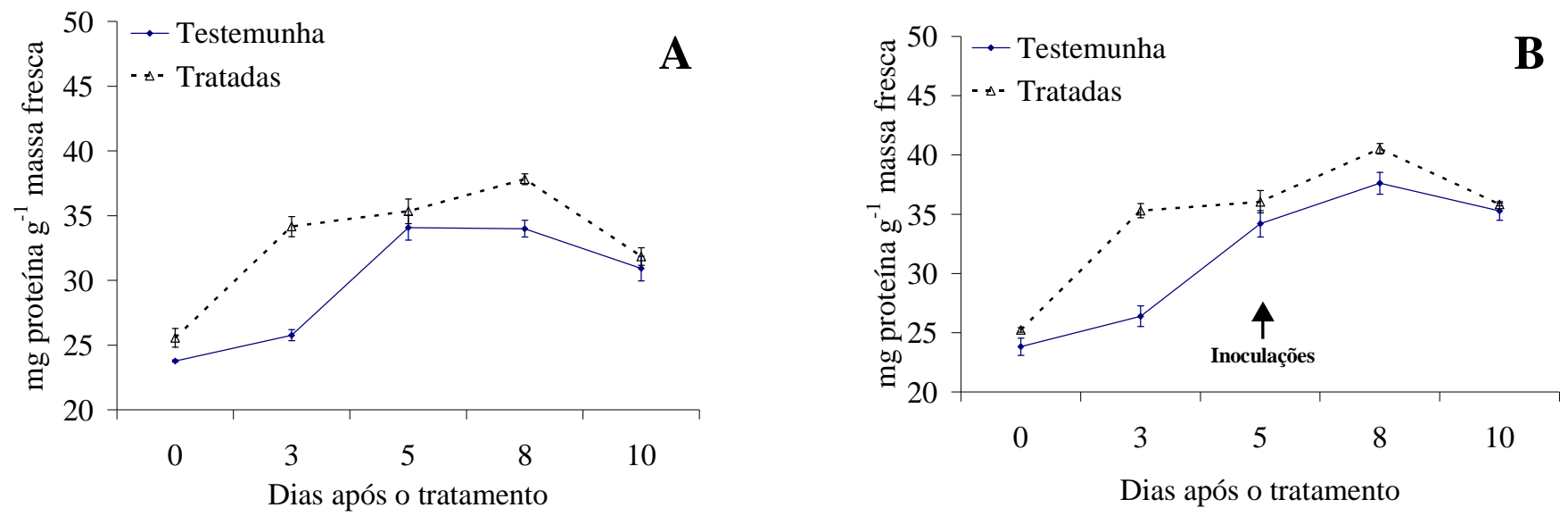

Figura 2 - Teor de polifenoloxidase, peroxidase e proteínas solúveis totais em folhas de feijão vagem cultivar Bragança pulverizadas com tintura de $L$. sidoides a $20 \%$, não inoculadas (A) e inoculadas (B) com X. axonopodis pv. phaseoli. Barras indicam a média \pm o erro padrão. 


\section{Polifenoloxidase}
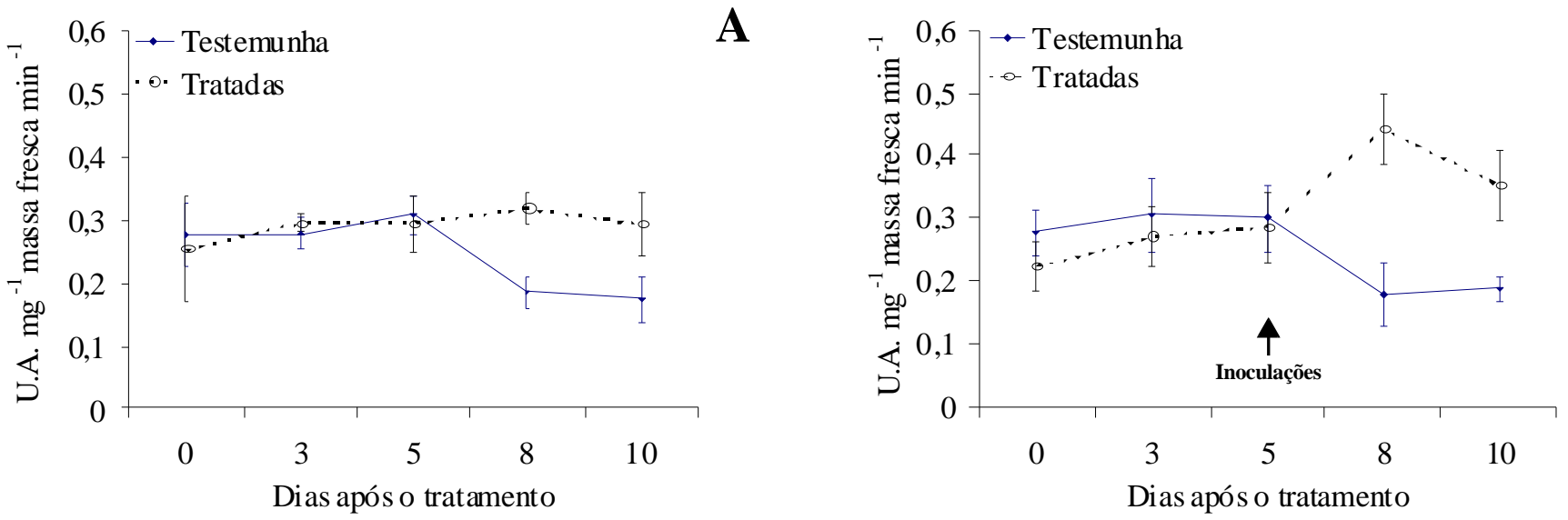

B

Peroxidase
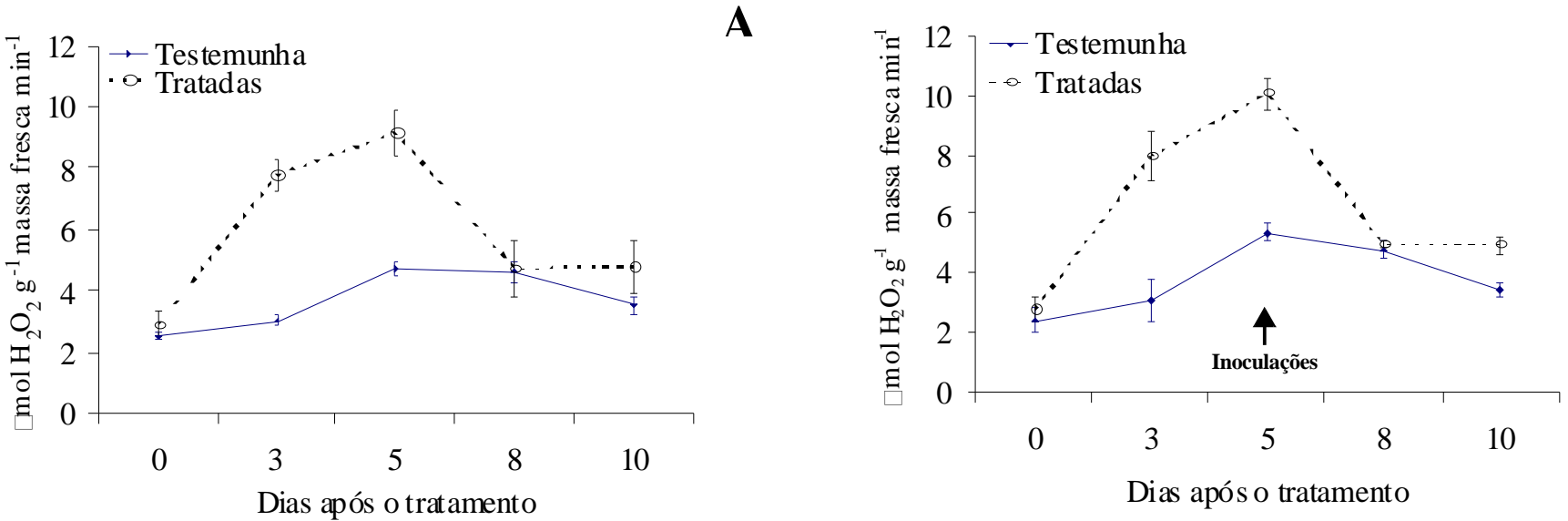

Proteínas solúveis totais
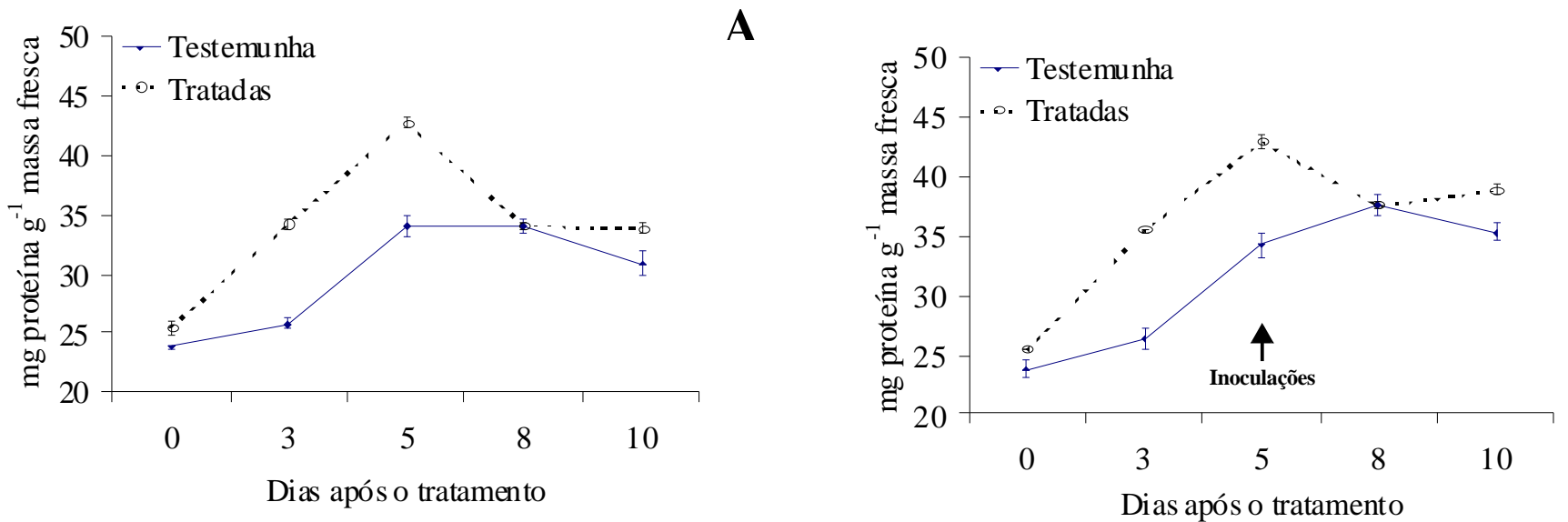

Figura 3 - Teor de polifenoloxidase, peroxidase e proteínas solúveis totais em folhas de feijão vagem cultivar Bragança pulverizadas com tintura de $M$. glomerata a $20 \%$, não inoculadas (A) e inoculadas (B) com X. axonopodis pv. phaseoli. Barras indicam a média \pm o erro padrão. 


\section{Polifenoloxidase}
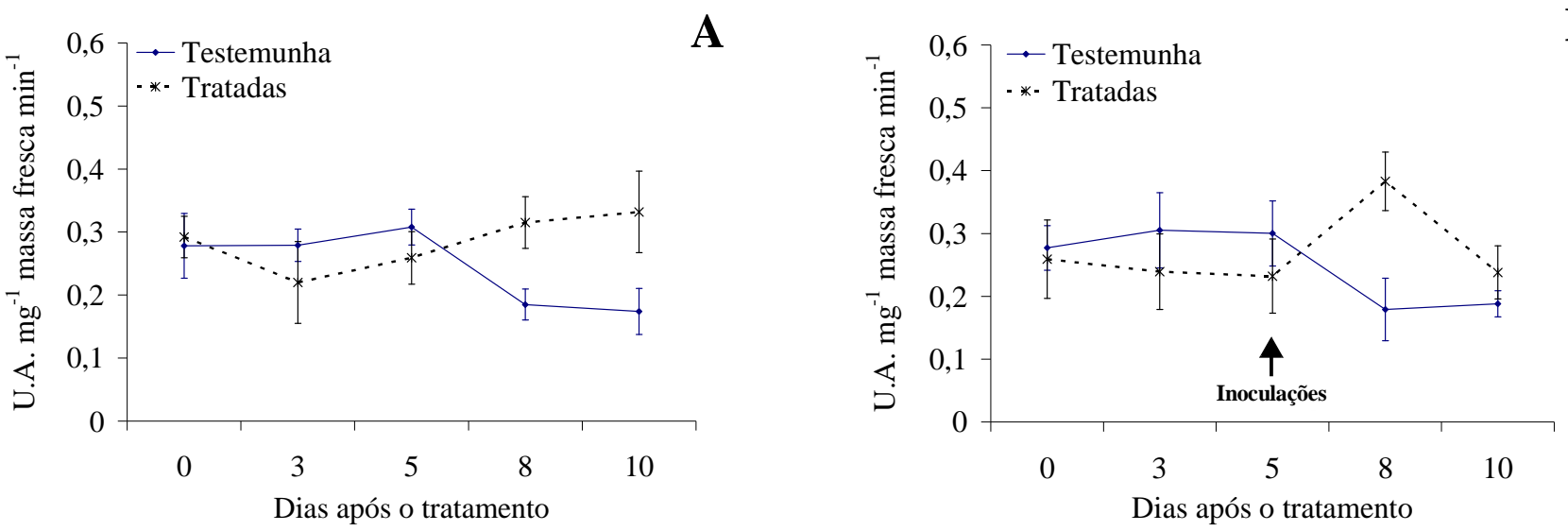

B

Peroxidase

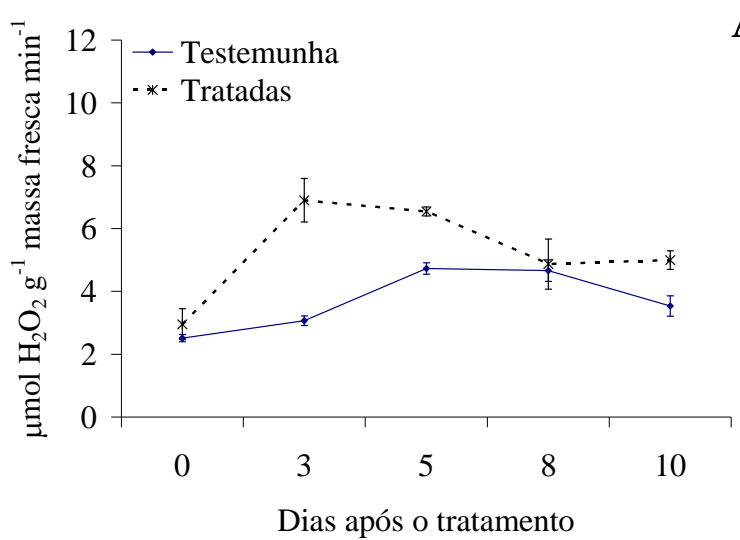

A

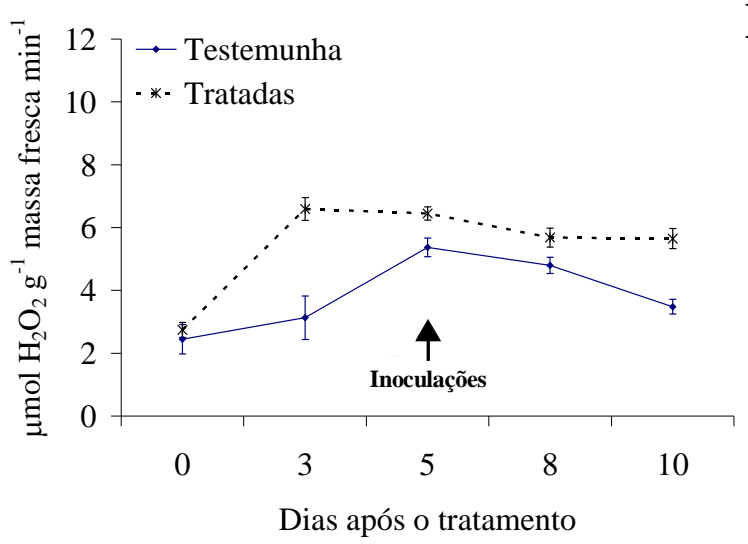

B

Proteínas solúveis totais
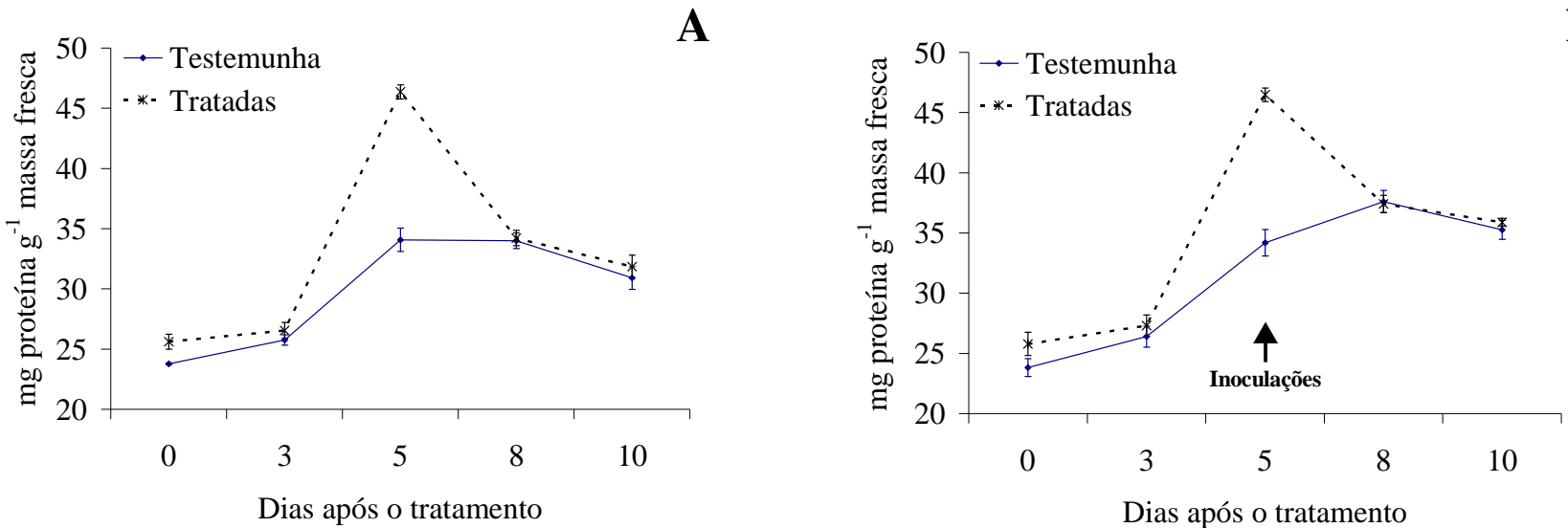

Figura 4 - Teor de polifenoloxidase, peroxidase e proteínas solúveis totais em folhas de feijão vagem cultivar Bragança pulverizadas com tintura de Equisetum sp. a 20\%, não inoculadas (A) e inoculadas (B) com X. axonopodis pv. phaseoli. Barras indicam a média \pm 0 erro padrão. 


\section{Polifenoloxidase}
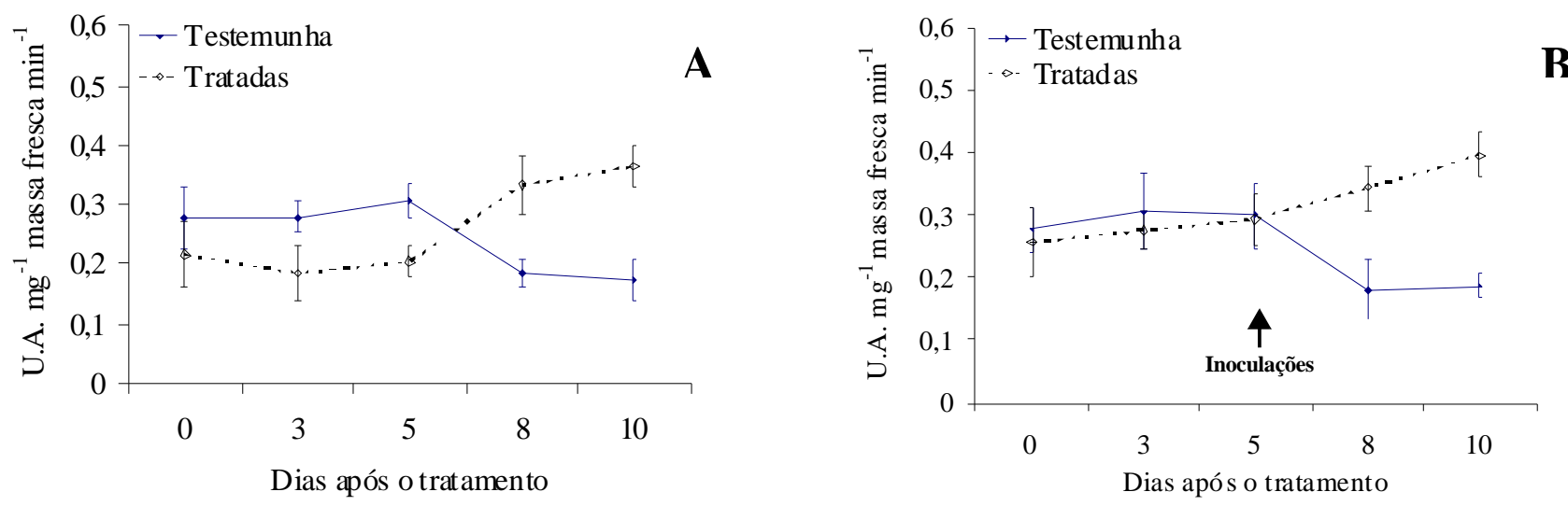

Peroxidase
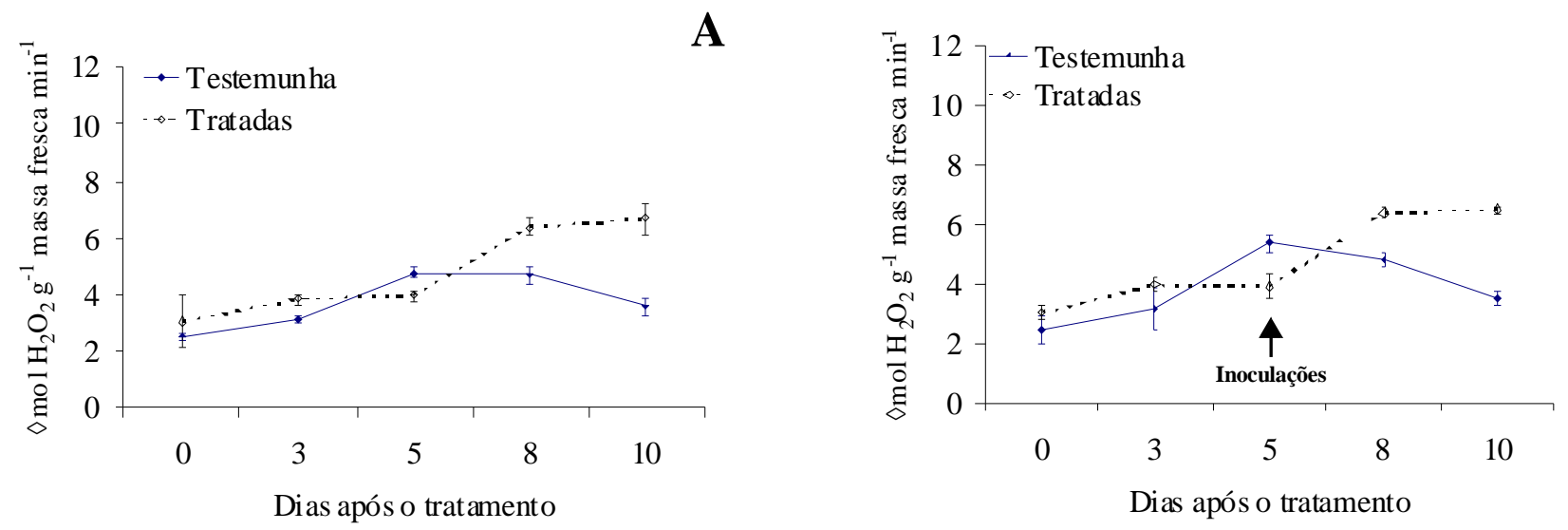

B

Proteínas solúveis totais

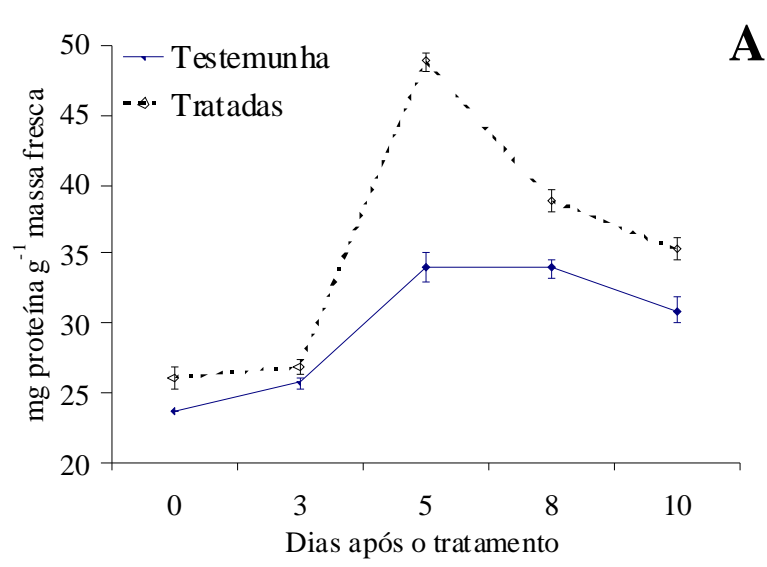

A

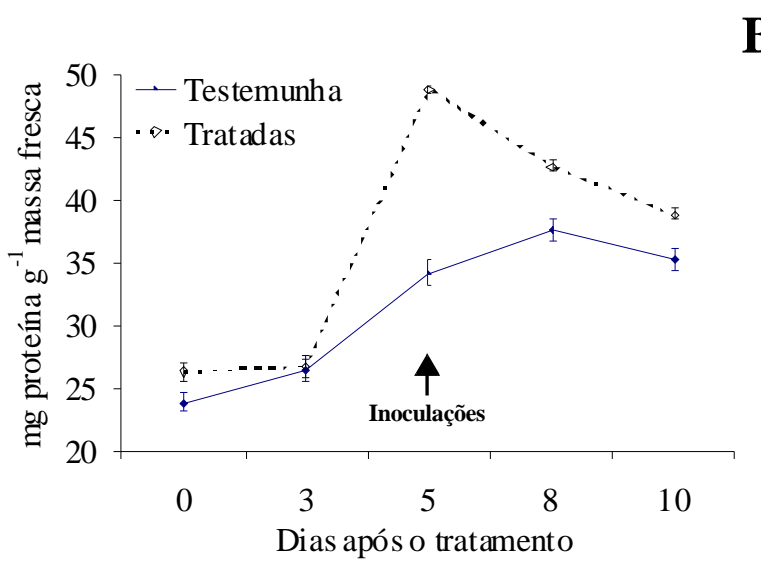

Figura 5 - Teor de polifenoloxidase, peroxidase e proteínas solúveis totais em folhas de feijão vagem cultivar Bragança pulverizadas com tintura de Hedera helix a 20\%, não inoculadas (A) e inoculadas (B) com X. axonopodis pv. phaseoli. Barras indicam a média \pm o erro padrão. 


\section{Polifenoloxidase}

A
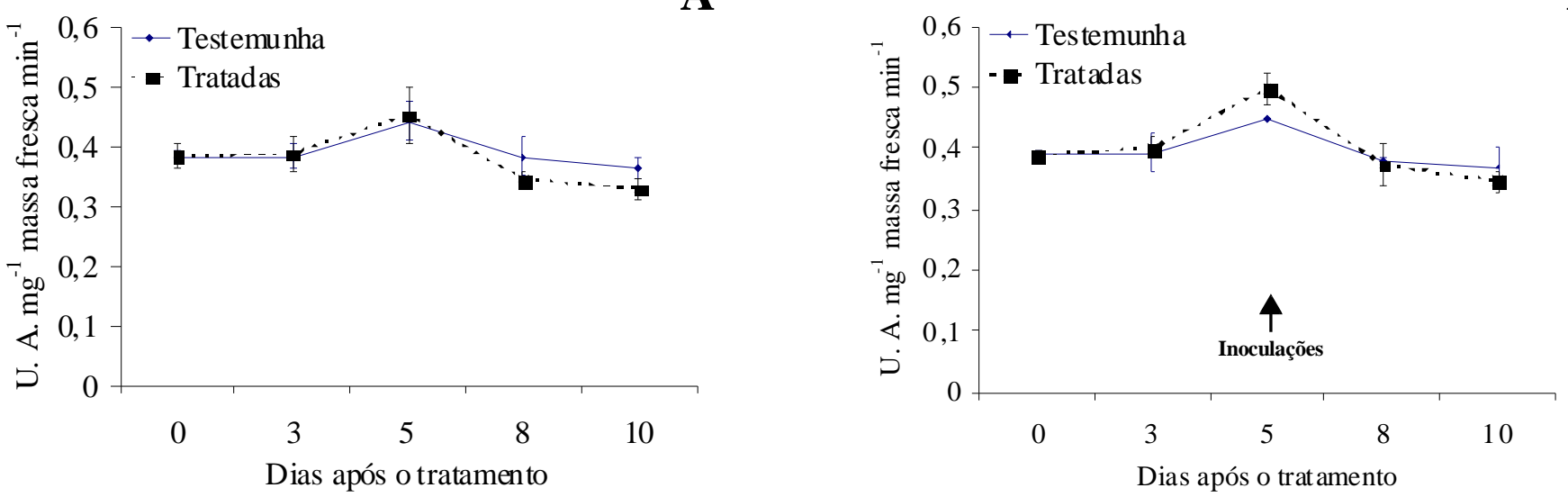

B

Peroxidase
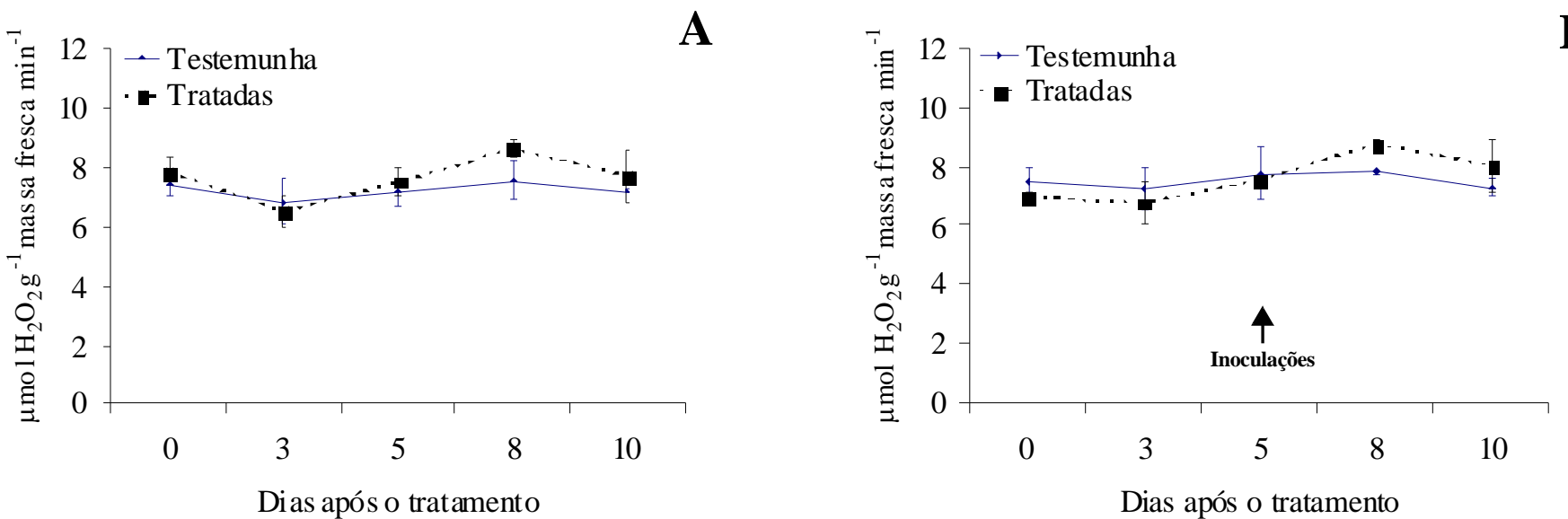

B

Proteínas solúveis totais
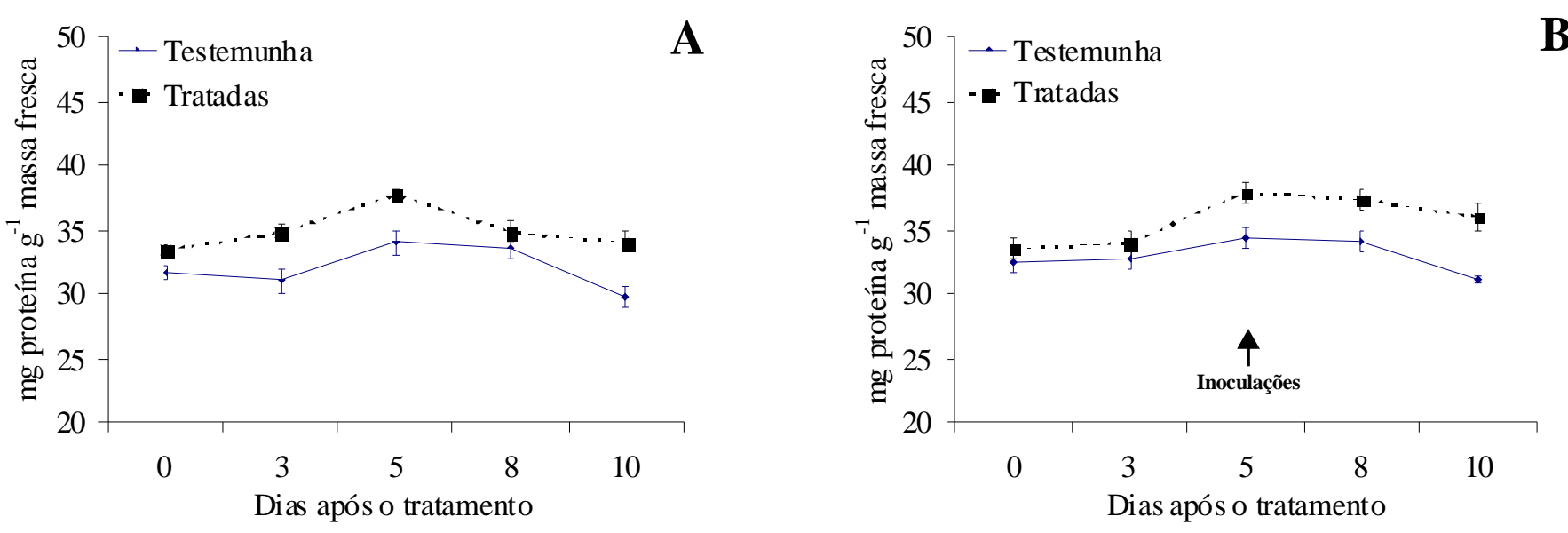

Figura 6 - Teor de polifenoloxidase, peroxidase e proteínas solúveis totais em folhas de feijão vagem cultivar Bragança pulverizadas com óleo essencial de $R$. officinalis a $0,5 \%$, não inoculadas (A) e inoculadas (B) com X. axonopodis pv. phaseoli. Barras indicam a média \pm o erro padrão. 


\section{Polifenoloxidase}

A
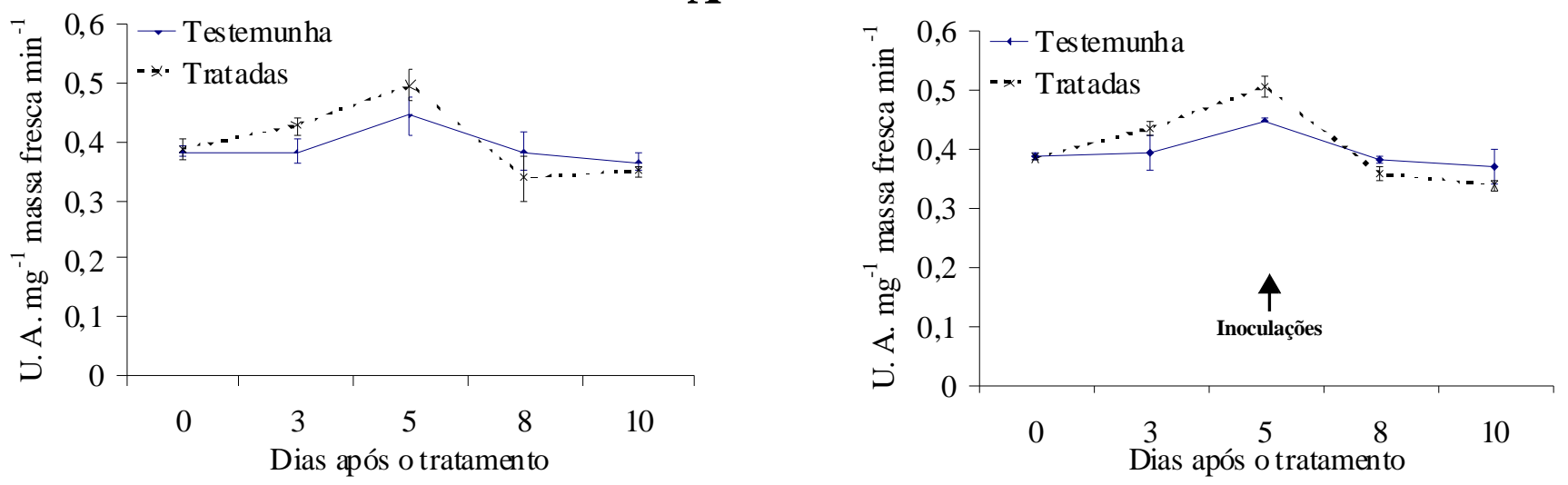

Peroxidase
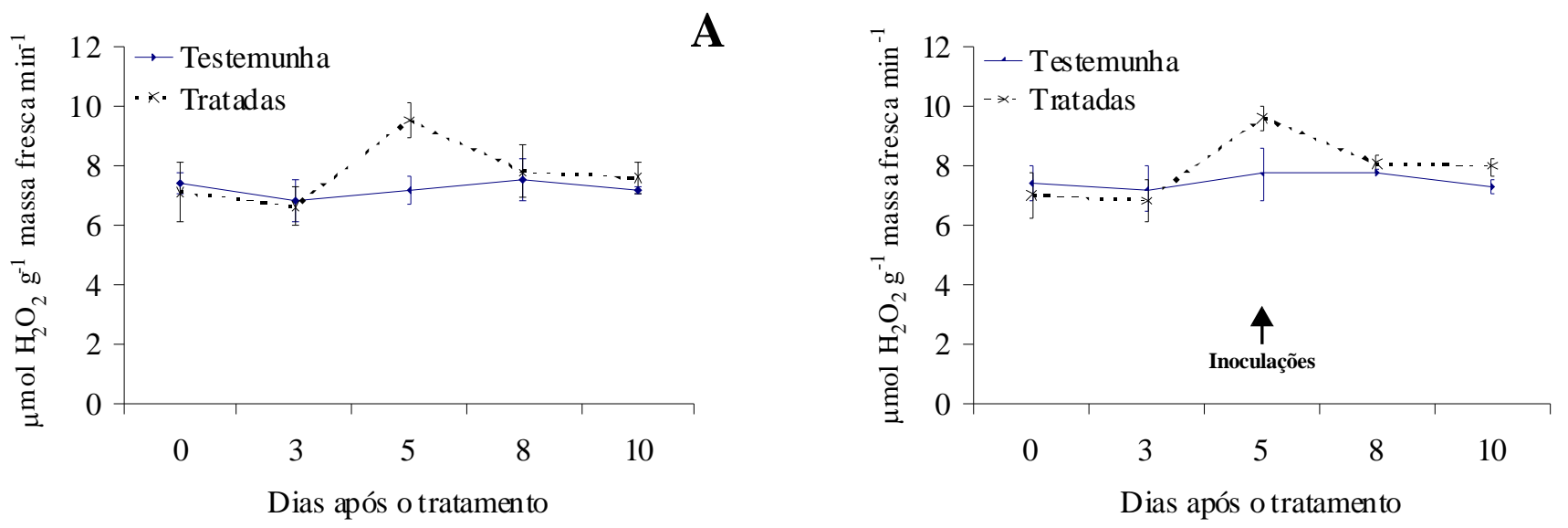

B

Proteínas solúveis totais
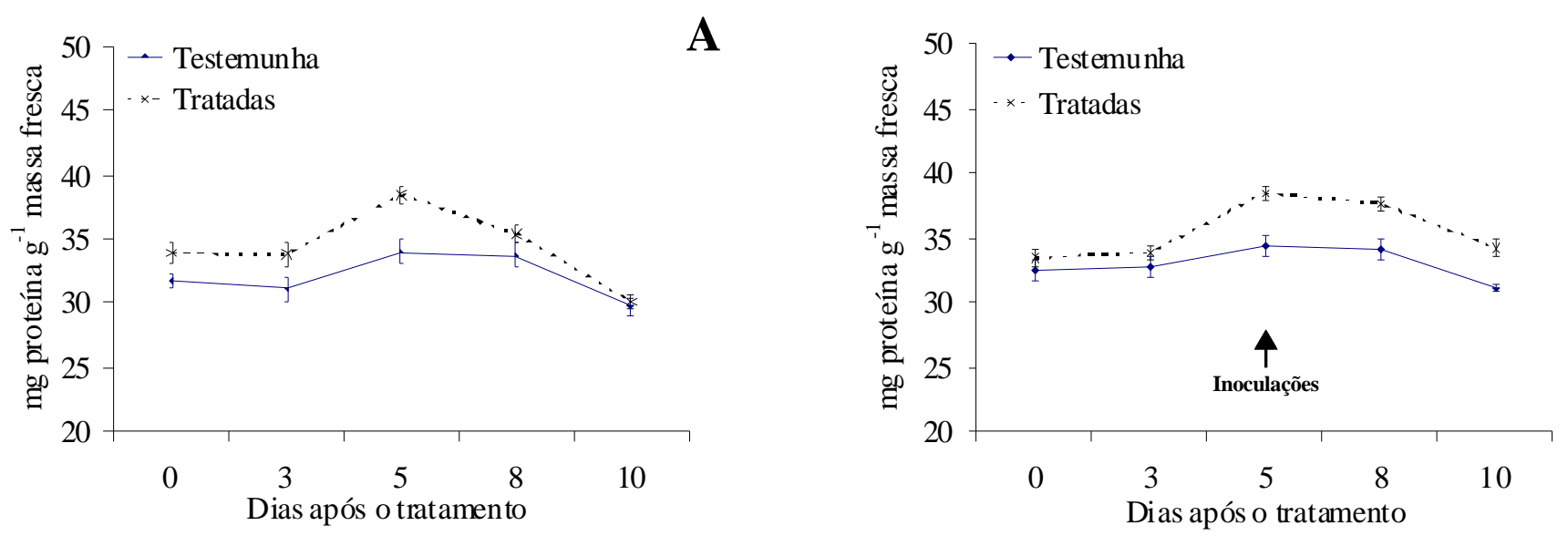

Figura 7 - Teor de polifenoloxidase, peroxidase e proteínas solúveis totais em folhas de feijão vagem cultivar Bragança pulverizadas com óleo essencial de C. zeylanicum a $0,1 \%$, não inoculadas (A) e inoculadas (B) com X. axonopodis pv. phaseoli. Barras indicam a média o erro padrão. 
solúveis totais para nenhuma das tinturas e ou óleos essenciais aqui ensaiados (Figuras 1 a 7). Já Silva et al. (20) observaram um aumento na peroxidase em plantas de tomate tratadas com extratos aquosos dos cogumelos Agaricus blazei e Lentinula edodes aos três dias após o tratamento e um dia após a inoculação, onde as plantas tratadas e inoculadas com a bactéria desafiante Ralstonia solanacearum apresentaram maior indução de peroxidase em relação a plantas somente tratadas com os extratos aquosos dos cogumelos. Em plantas de pepino tratadas com extrato aquoso de L. edodes e desafiadas com Colletotrichum lagenaria, Di Piero e Pascholati (06) constataram uma elevação na atividade local e sistêmica de peroxidases no nono e décimo segundo dias após o tratamento, respectivamente (no terceiro e sexto dia após a inoculação do patógeno).

\section{REFERÊNCIAS BIBLIOGRÁFICAS}

1. ANDRUS, C.F. A method of testing beans for resistance to bacterial blights. Phytopathology, v. 38, p. 757-759, 1948.

2. Barros, B.C.; Oliveira, S.H.F.; Leite, L.G.; Ito, M.F.; Campos, T.B.; Oliveira, C.M.G.; Sanazzaro, A.M.; Castro, J.L. \& Pinzan, N.R.. Manejo integrado de pragas e doenças do feijoeiro. São Paulo: Secretaria de Agricultura e Abastecimento, 2000, v. 3, 39p. (Manual Técnico, Série Especial).

3. Bianchini, A.; Maringoni, A.C. \& Carneiro, S.M.T.P.G. Doenças do feijoeiro. In: Kimati, H.; Amorim, L.; Rezende, J.A.M.; Bergamin Filho, A \& Camargo, L.E.A. (Ed.) Manual de Fitopatologia: Doenças das plantas cultivadas, São Paulo: Agronômica Ceres, 2005. v. 2, p. 333-349.

4. Bradford, M.A. A rapid and sensitive method for the quantitation of microgram quanties of protein utilizing the principle of protein-dye binding. Analytical Biochemistry, New Delhi, v. 72, p. $248-254,1976$.

5. Cano, M.P.; Ancos, B.; Mantallana, M.C.; Cámara, M.; Reglero, G. \& Tabea, J.. Differences among Spanish and Latin-American banana cultivars: morphological, chemical and sensory characteristics. Food Chemistry, Barking, v. 59, n. 3, p. 411-419, 1997.

6. Di Piero, R.M. \& Pascholati, S.F. Indução de resistência em plantas de pepino contra Colletotrichum lagenarium pela aplicação de extratos de basidiocarpos de Lentinula edodes e de Agaricus blazei. Summa Phytopathologica, v.30, p.243-250. 2004.

7. Junqueira, N.T.V.; Chaves, R.C.; Nascimento, A.C.; Ramos, V.H.V.; Peixoto, J.R. \& Junqueira, L.P. Efeito do óleo de soja no controle da antracnose e na conservação da manga cv. Palmer em póscolheita. Revista Brasileira de Fruticultura, Jaboticabal, v. 26, n. 2, p. 222-225, 2004.

8. Lima, G.P.P. Efeito do cálcio sobre o teor de poliaminas, peroxidase e nitrato redutase em calos de arroz (Oryza sativa L. cv. IAC 4440). 1994. 84 f. Tese (Doutorado). Instituto de Biociências, Universidade Estadual Paulista, Botucatu.

9. Maringoni, A.C.; Fregonese, C.H.; Tofoli, J.G \& Kurozawa, C. Reação foliar e de vagens de feijoeiro a Xanthomonas campestris pv. phaseoli e transmissão da bactéria pelas sementes. Fitopatologia Brasileira, Brasília,v. 18, n. 3, p. 412-415, 1993.

10. Morais, L.A.S. et al. Evaluation of antimicrobial activity of extracts of medicinal plants on three tomato phytopathogens. Acta
Horticulturae, n. 579, p. 87-90, 2002.

11. Morais, L.A.S.; Maringoni, A.C. \& Ming, L.C. Atividade de tinturas de plantas medicinais in vitro sobre Xanthomonas axonopodis pv. phaseoli. Horticultura Brasileira, Brasília, v. 20, n. 2, 2002. Suplemento CD-room.

12. Paixão, G. L. de S.; Seabra Jr, S.; Morais, L. A. S. de; Biazon, V. L.; Goto, R.; Maringoni, A. C. \& Ming, L. C. Atividade de tinturas de plantas medicinais sobre o crestamento bacteriano comum em feijão vagem. Horticultura Brasileira, Brasília, v. 21, 2003. Suplemento CD-room.

13. Ranasinghe, L.; Jayawardena, B. \& Abeywickrama, K. Fungicidal activity of essential oils of Cinnamomum zeylanicum (L.) and Syzygium aromaticum (L.) Merr et L.M.Perry against crown rot and anthracnose pathogens isolated from banana. Letters in Applied Microbiology, v. 35, p. 208-211, 2002.

14. Resende, M.L.V.; Nojosa, G.B.A.; Cavalcanti, L.S.; Aguilar, M.A.G.; Silva, L.H.C.P.; Perez, J.O.; Andrade, G.C.G.; Carvalho, G.A. \& Castro, R.M. Induction of resistance in cocoa against Crinipellis perniciosa e Verticillium dahliae by acibenzolar-Smethyl (ASM). Plant Phathology, San Diego, v. 51, p. 621628, 2002.

15. Schneider, R.W.; Williams, R.J. \& Sinclair, J.B. Cercospora leaf sport of cowpea: models for estimating yield loss. Phytopatho$\log \mathbf{y}, 66: 384-388,1976$.

16. Schwan-Estrada, K.R.F.; Stangarlin, J.R.; Cruz, M.E.S. Uso de plantas medicinais no controle de doenças de plantas. Fitopatologia Brasileira, Brasília, v. 28 (suplemento), p. 554 - 556, 2003.

17. Schwan-Estrada, K.R.F. \& Stangarlin, J.F. Extratos e óleos essenciais de plantas medicinais na indução de resistência. In: Cavalcanti, L.S., Di Piero, R.M., Cia, P., Pascholati, S.F., Resende, M.L.V. \& Romeiro, R.S. (Eds.) Indução de resistência em plantas a patógenos e insetos. Piracicaba SP. FEALQ. 2005. p. 125-138.

18. Silva, F. de A.S. e \& Azevedo, C.A.V. de. A New Version of The Assistat-Statistical Assistance Software. In: World Congress on Computers in Agriculture, 4, Orlando: Anais... Orlando: American Society of Agricultural Engineers, p.393-396, 2006.

19. Silva, R.F. Indução de resistência em plantas de berinjela e tomate por Lentinula edodes e Agaricus blazei contra bactérias causadoras de murcha (Ralstonia solanacearum) e cancro (Clavibacter michiganensis subsp. Michiganensis). 2007, $109 \mathrm{f}$. Tese (Doutorado na área de Fitopatologia), Universidade de São Paulo, Piracicaba, 2007.

20. Silva, R.F., Pascholati, S.F. \& Bedendo, I.P. Indução de resistência em tomateiro por extratos aquosos de Lentinula edodes e Agaricus blazei contra Ralstonia solanacearum. Fitopatologia Brasileira, v.32, n. 3, p.189-196. 2007.

21. Trani, P.E.; Passos, F.A. Recomendações de adubação e calagem para o Estado de São Paulo. Campinas: IAC, 1997, 180 p. (Boletim técnico 100).

22. Tworkoski, T. Herbicide effects of essential oils. Weed Science, v. 50, p.425-431, 2002.

23. Vigo-Schultz, S.C.; Stangarlin, J.L.; Franzener, G.; Portz, R.L.; Kuhn, O.J. \& Schwan-Estrada, K.R.F. Avaliação da eficácia da tintura etanólica de guaco (Mikania glomerata) no controle da podridão negra (Xanthomonas campestris pv. campestris) em couve-flor. Semina: Ciências Agrárias, Londrina, v. 27, n. 4, p. $515-524,2006$ 